\title{
Study on personality dimension negative emotionality affecting academic achievement among Malaysian medical students studying in Malaysia and overseas
}

\author{
This article was published in the following Dove Press journal: \\ Advances in Medical Education and Practice \\ II June 2016 \\ Number of times this article has been viewed
}

\section{Vidya Bhagat ${ }^{1}$ \\ Mainul Haque ${ }^{2}$ \\ Nordin Bin Simbak' \\ Kamarudin Jaalam ${ }^{3}$ \\ 'Faculty of Medicine, Universiti Sultan Zainal Abidin, Jalan Sultan Mahmud, Kuala Terengganu, Malaysia; ${ }^{2}$ Faculty of Medicine and Defense Health, National Defence University of Malaysia, Kuala Lumpur, Malaysia; ${ }^{3}$ USM-KLE International Medical Program, Belgaum, Karnataka, India}

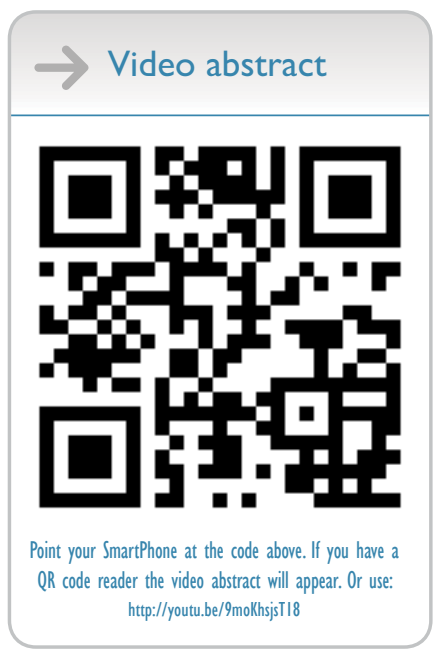

Correspondence: Vidya Bhagat Unit of Psychological Medicine, Faculty of Medicine (FP), Medical Campus, Universiti Sultan Zainal Abidin, Jalan Sultan Mahmud, 20400 Kuala Terengganu,

Terengganu, Malaysia

Email 55vidya42@gmail.com

\begin{abstract}
Personality dimension negative emotionality is known to be associated with academic achievement. The present study focuses on the influence of negative emotionality (neuroticism) on the medical students' academic achievements. The main objective of this study was to ascertain the negative emotionality scores among the first year Malaysian medical students studying in Malaysia and India, further to find out the association between negative emotionality and their academic achievements. The current study sample includes 60 first year Malaysian medical students from Universiti Sultan Zainal Abidin, Malaysia, and USM-KLE IMP, Belgaum, India. They were selected by convenient sampling technique. The Medico-Psychological questionnaire was used to find out the negative emotionality scores among the students and these scores were compared with academic scores. The data were analyzed using SPSS- 20 . Thus, the study result goes with the prediction that there is a significant correlation between academic achievement and negative emotionality. We concluded that negative emotionality has a negative impact on medical student's academic achievement regardless of the fact whether they study in their own country or overseas.
\end{abstract}

Keywords: academic achievement, negative emotionality, Malay, medical students, Malaysia

\section{Introduction}

Negative emotionality is generally defined as the tendency to show various forms of negative affect. This is a personality trait characterized by anxiety, moodiness, worry, envy, and jealousy. ${ }^{1-3}$ Individuals who score high on neuroticism are more likely to experience feelings such as anxiety, anger, envy, guilt, and low mood in a stress-inducing environment. ${ }^{4}$ People with this trait respond poorly to stress and interpret ordinary situations as threatening and they find minor frustrations as hopelessly difficult. ${ }^{5}$ Students with this trait are often self-conscious and shy in behavior and also have trouble controlling urges and thus delaying gratification. ${ }^{6}$ According to Eysenck's (1967) theory of personality, neuroticism is interlinked with low tolerance for stress or aversive stimuli. ${ }^{7}$ Their negative emotional reactions tend to persist for unusually long periods of time. These problems in emotional regulation diminish the ability of a person to think with clarity, make decisions, and cope with stress. These disturbances in psychological homeostasis affect the academic performance of medical students. Generally, it is believed that lack of 
satisfaction and gratification in one's life achievements can correlate to high neuroticism scores and increase a person's likelihood of falling into clinical depression. ${ }^{8}$ Medical students suffer from stress during their training period and negative emotionality gets exaggerated, which have a negative influence on their coping ability. ${ }^{9,10}$ At the commencement of their medical schooling students need to identify the demands which lead to their being stressed. Reasons for their stresses include the following: living away from home, transition to a more independent living with less supported condition, and coping with students' demands. Furthermore, exposure to serious illnesses and deaths may provoke a stressful reaction among medical students. ${ }^{11,12}$ Studies that have tried to identify the sources of stress among medical students generally pointed to three main areas: academic pressures, social issues, and financial problems. ${ }^{13-19}$ The majority of stressful incidents in traditional curricula are related to medical training rather than to personal problems. ${ }^{14-17}$ Workload and feeling overwhelmed by the information load are major sources of stress. Fears of failing or falling behind are particular preoccupations. ${ }^{13-17}$ In the UK, the General Medical Council recommends that medical schools should have mechanisms in place to identify symptoms of stress that might be early signs of mental health issues or illness. ${ }^{20-23}$ Medical schools in the US and Canada tackle the problem at an earlier stage by undertaking prevention in the form of health promotion programs. ${ }^{24,25}$ These interventions have been shown to reduce the effects of stress on medical student's health and academic performance. ${ }^{26-29}$ Staying with strong emotions requires a high degree of awareness because intense emotions can take over reasoning powers. Maintaining awareness during emotional processing will allow you to "ride the waves". ${ }^{30}$ A number studies evidenced that Year-I medical students suffer from negative emotionality over the globe including Malaysia. ${ }^{31-33}$ Malaysian medical education usually is a 5-year program with 2 years of housemanship in hospitals owned by Ministry of Health, Malaysia. ${ }^{17,18}$ Almost all medical schools of Malaysia have a module focusing on professional personality development. ${ }^{34-36}$ Although this module exists throughout the 5-year course, more emphasis is on the preclinical students of Year I and II.

\section{Hypothesis}

It has been hypothized that negative emotionality score significantly affects the academic achievement of medical students.

\section{Objectives}

The objectives of this study were to assess the extent of negative emotionality among Year-I medical students and to evaluate the impact of negative emotions on academic performance of the Malaysian medical students studying in native country and overseas. Therefore, this study has made an effort to explore the influence of negative emotionality on Malay medical student's academic achievements in new medical schools in Malaysia and India.

\section{Materials and methods}

The study adopted descriptive survey with evaluative approach and cross-sectional research design. The subjects of the study were medical students of Year I from the Universiti Sultan Zainal Abidin (UniSZA), Kuala Terengganu, Malaysia, and the Malaysian students studying overseas in Universiti Sains Malaysia-KLE Society India International Medical Program (USM-KLE IMP), Belgaum, India. Students were selected by convenient sampling technique during their professional personality development sessions. "Convenience sampling involves drawing samples that are both easily accessible and willing to participate in a study". 37 "It is the least costly to the researcher, in terms of time, effort and money. There is an element of convenience sampling in many qualitative studies, but a more thoughtful approach to selection of a sample is usually justified." ${ }^{38}$ USM-KLE IMP is a medical school especially for Malaysian medical students at Belgaum, India. This school maintains and promotes similar medical education system as per Malaysian Medical Council. As Dr Vidya Bhagat worked in both the medical schools, it was easy to select the study sample. Sixty medical students from each institute were assessed to measure their extent of negative emotionality as a dimension of personality. The students were voluntarily involved in the survey.

\section{The assessment tool}

Medico-psychological questionnaire was used to measure the variables. This questionnaire is a standardized scale developed by Dr Bharathraj for neurosis and it consists of 50 items based on five neurotic traits - hysteria, anxiety neurosis, neurasthenia, reactive depression, and obsessive-compulsive disorder. The negative, positive, and doubtful responses are scored to obtain the negative emotionality score. The academic scores of the participating students were collected from the academic office of respective colleges with the consent of higher authorities. ${ }^{39}$ The study instrument was validated prior to this study and has been extensively used all over India and also in Malaysia. 


\section{Study group}

Sixty Year-I medical students from each institution were recruited for the study. The study instrument was again pretested and validated. Most of the sections of this questionnaire demonstrated acceptable values, with a range between 0.672 and 0.882 , which indicated that both instruments possessed good internal consistency and reliability. Convergent validity was evidenced by significant correlations between the items of each section and the total mean in each section $\left(r_{s}=\right.$ $0.332-0.718 ; P<0.05){ }^{40,41}$ Therefore, the total participants were 120.

\section{Study period}

Study was conducted from February to July in the year 2014.

\section{Data analysis}

Data were keyed in and analyzed using SPSS 20 (IBM Corporation, Armonk, NY, USA). Fisher's exact test and Pearson's chi-square test were used to analyze the data.

\section{Ethical approval}

This study was approved by the ethical committee of both UniSZA and USM-KLE IMP. Informed written consent was obtained from each and every study participant.

\section{Results}

Of the study participants from UniSZA and USM-KLE IMP, 20 students were male, ten from each institution. Their age range was 18-21 years. All the research participants belonged to Malay race and Islamic religion. Among the 120 participants, 26 and 94 medical students were found to be stable and unstable, respectively. Among the participants from USM-KLE IMP, ten and 50 students were found to be stable and unstable, respectively, whereas from UniSZA, 16 and 44 students were found to be stable and unstable, respectively. Stable emotion is defined as one's feeling of self-worth and security, whereas unstable emotion means one's actions reflect a strong sense of power, responsibility and self-determination, as opposed to submissiveness to intrapsychic or externally based pressures..$^{42-45}$

Among the 60 participants who belonged to USM-KLE IMP, only ten students scored $\geq 60$ marks who were considered stable, and the remaining 50 students were considered unstable. Among them, 34 and 16 students scored $\geq 60$ marks and $\leq 60$ marks, respectively. There was a statistically significant $(P=0.05)$ difference observed between stable and unstable group of USM-KLE IMP (Table 1). Almost a similar result was observed among the participants who belonged to
Table I The association between negative emotionality and academic achievements of USM-KLE IMP students $(n=60)$

\begin{tabular}{|c|c|c|c|}
\hline \multirow[t]{2}{*}{ Neuroticism } & \multicolumn{2}{|l|}{ Scores } & \multirow[t]{2}{*}{$P$-value ${ }^{a}$} \\
\hline & $\begin{array}{l}\text { Above the average } \\
\text { ( } \geq 60 \text { marks) }\end{array}$ & $\begin{array}{l}\text { Below the average } \\
\text { ( } \leq 60 \text { marks) }\end{array}$ & \\
\hline Stable & $10(100.0 \%)$ & $0(0.0 \%)$ & \multirow[t]{2}{*}{0.050} \\
\hline Unstable & $34(68.0 \%)$ & $16(32.0 \%)$ & \\
\hline \multirow{2}{*}{\multicolumn{4}{|c|}{$\begin{array}{l}\text { Abbreviations: USM-KLE IMP, Universiti Sains Malaysia-KLE Society India } \\
\text { International Medical Program. } \\
\text { Note: 'Fisher's exact test. } \\
\text { Table } 2 \text { The association between negative emotionality and } \\
\text { academic achievements of UniSZA students }(n=60)\end{array}$}} \\
\hline & & & \\
\hline \multirow[t]{2}{*}{ Neuroticism } & \multicolumn{2}{|l|}{ Scores } & \multirow[t]{2}{*}{$P$-value ${ }^{a}$} \\
\hline & $\begin{array}{l}\text { Above the average } \\
\text { ( } \geq 60 \text { marks) }\end{array}$ & $\begin{array}{l}\text { Below the average } \\
\text { ( } \leq 60 \text { marks) }\end{array}$ & \\
\hline Trabte & $16(100.0 \%)$ & $0(0.0 \%)$ & 0.001 \\
\hline Unstable & 23 (52.3\%) & 21 (47.7\%) & \\
\hline
\end{tabular}

Abbreviations: UniSZA, Universiti Sultan Zainal Abidin.

Note: aPearson's chi-square test.

Table 3 The association between negative emotionality and their academic achievements of all students $(n=120)$

\begin{tabular}{|c|c|c|c|}
\hline \multirow[t]{2}{*}{ Neuroticism } & \multicolumn{2}{|l|}{ Scores } & \multirow[t]{2}{*}{$P$-value ${ }^{a}$} \\
\hline & $\begin{array}{l}\text { Above the average } \\
(\geq 60 \text { marks) }\end{array}$ & $\begin{array}{l}\text { Below the average } \\
(\leq 60 \text { marks) }\end{array}$ & \\
\hline Stable & $26(100.0 \%)$ & $0(0.0 \%)$ & 0.0001 \\
\hline Unstable & 57 (60.64\%) & 37 (39.36\%) & \\
\hline
\end{tabular}

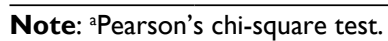

Table 4 Comparison of negative emotionality between UniSZA and USM-KLE IMP students $(n=120)$

\begin{tabular}{llll}
\hline Neuroticism & \multicolumn{2}{l}{ Students } & P-value $^{\mathbf{a}}$ \\
\cline { 2 - 3 } & UniSZA & USM-KLE IMP & \\
\hline Stable & $16(61.5 \%)$ & $10(38.5 \%)$ & 0.184 \\
Unstable & $44(46.8 \%)$ & $50(53.2 \%)$ & \\
\hline
\end{tabular}

Abbreviations: UniSZA, Universiti Sultan Zainal Abidin; USM-KLE IMP, Universiti Sains Malaysia-KLE Society India International Medical Program.

Note: Pearson's chi-square test.

UniSZA - only 16 students scored $\geq 60$ marks who were considered stable and the remaining 44 students were considered unstable. Among them, 23 and 21 scored $\geq 60$ marks and $\leq 60$ marks, respectively. Among the participants from UniSZA, a high statistically significant $(P=0.001)$ differences were observed between the stable and unstable group (Table 2). There was a statistically significant difference $(P=0.0001)$ between negative emotionality and academic achievement when compared to all students of the study (Table 3). No statistically significant differences were observed for negative emotionality $(P=0.184$; Table 4$)$ and academic achievements 
Table 5 Comparison of academic achievements between UniSZA and USM-KLE IMP students $(n=120)$

\begin{tabular}{llll}
\hline Scores & \multicolumn{2}{l}{ Students } & P-value $^{\mathbf{a}}$ \\
\cline { 2 - 3 } & UniSZA & USM-KLE IMP & \\
\hline $\begin{array}{l}\text { Above the average } \\
\begin{array}{l}\geq 60 \text { marks) } \\
\text { Below the average }\end{array}\end{array}$ & $21(47.0 \%)$ & $44(53.0 \%)$ & 0.323 \\
( $\leq 60$ marks) & & & \\
\hline
\end{tabular}

Abbreviations: UniSZA, Universiti Sultan Zainal Abidin; USM-KLE IMP, Universiti Sains Malaysia-KLE Society India International Medical Program.

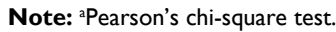

$(P=0.323$; Table 5) between the students of UniSZA and USM-KLE IMP.

\section{Discussion}

The current study revealed that the 60 Malaysian medical students from each of the medical schools studying in Malaysia and India, respectively, vary in their personality trait neuroticism. The forecasted views in the hypothesis that negative emotions affect students' academic achievement has been theorized in the current study (Tables 1-3). Although no statistically significant differences were observed among the two groups of students (Tables 4 and 5), the overall group showed a significant negative emotionality affecting their academic score (Table 3 ). Negative emotionality is a personality dimension that has a negative effect on the student's academic achievement. ${ }^{28,46}$ Henceforth, the current study findings were found to be consistent with other studies. ${ }^{28,39}$ The optimal level of academic achievement and the negative emotionality score of students should be less than $16 .^{29}$

The correlation between the two variables, negative emotionality score and academic achievement, was found to be significant in the present study, despite the fact that students studying in their own country and overseas showed no statistically significant differences (Tables 4 and 5). Multiple studies have reported that living and studying overseas at many occasions increase stress and mental illness. ${ }^{47,48}$ USM-KLE IMP is a medical school in India but follows the curriculum as per Malaysian Medical Council and Quality Assurance authority. USM-KLE IMP mainly admit Malaysian students with the rare exception of a few foreigners. Therefore, the current study sample did not have the additional demands of adapting to a new a new culture and were better able to cope. A number of studies have reported that studying and living overseas very often decreases stress and other coping difficulties with similar sociocultural environment. ${ }^{49-53}$ Although they lived overseas, they almost had their own style of living. Nevertheless, the Malaysian medical students studying in Indian medical schools had to cope up and adjust with the Indian students, who are from different sociocultural background, and also with Indian medical educational system. Therefore, for the current study, we selected students who belonged to the same ethnicity and nationality so as to obtain similar results. However, the study results obtained are in agreement with our predicted hypothesis - high negative emotionality scores are associated with lower academic achievement in the overall group.

The overall result brings out the importance of conceptualizing the positive and negative effects of the emotional dimension and trait personality toward academic achievement. The findings of this study are consistent with the meta-analysis that has provided the first comprehensive empirical review of the validity of the Eysenck's personality scales as statistical predictors of academic performance. ${ }^{54}$ As expected, academic performance of medical students were significantly associated with neuroticism. ${ }^{54}$ A Romanian study stated that the personality factors associated with the academic stress of first year medical students were predicted by trait anxiety, sex, and neuroticism; this study also share similar views with the current study. ${ }^{55}$ One multicenter Flemish study on medical students' personality characteristics and academic performance found that the medical student scores were highest on extroversion and agreeableness. ${ }^{56}$ Medical students who scored high in gregariousness, neuroticism, and excitement-seeking are significantly less likely to successfully appear for examination. ${ }^{56}$ One metaanalytic study that analyzed the relationship between big five personality traits and students' academic achievement in a public university of Malaysia found that personality is likely to play significant roles in influencing students' academic achievement. This study also shares similar views with the current study. ${ }^{54}$ Therefore, it is important to optimize the achievement of students not only in academics but also in other fields as we know that the future of our country lies in these budding personalities.

\section{Limitations of the study}

This is a cross-sectional study and has its inherent limitation. Moreover, sample size was only 120 . Therefore, it is quite difficult to generalize the study findings. Students' anxiety, socioeconomic, genetic, and intellectual aspects also contribute to academic achievement. The current study did not explore these areas because of insufficient time and no research fund was obtained. Therefore, more extensive research in this regard is advocated to promote and produce more holistic medical doctors for the community. 


\section{Conclusion}

This study has analyzed negative emotionality and its association with academic achievement and has ascertained that the negative emotions of Malaysian medical students studying in Malaysia and overseas, regardless of their residential location, have significantly affected their academic performance. Medical students of UniSZA, Malaysia, are more concerned about negative emotionality than students of USM-KLE IMP, India, in this aspect. Although the students studying overseas are affected, no statistical significance was observed regarding the association between negative emotionality and their academic achievements. Thus, the result of the current study theorizes the hypothetical view. This study also emphasizes that negative emotionality has an adverse impact on medical student's academic achievement regardless of the fact whether they study in their own country or overseas. This study emphasizes that students should develop awareness regarding their emotionality and self-regulate their emotional stability; thereby, they can improve their academic achievement and professional personality. In addition, medical institutions can also make use of this result to mend and guide their students to optimize their skills and abilities in order to help them to achieve better in their academics. Since the professional development and mentor-mentee program exist in both the universities, this information can be used by the faculties in their professional personality development sessions held for medical students. And mentors of each students can use this information in menting their mentees.

\section{Disclosure}

The authors report no conflicts of interest in this work.

\section{References}

1. Ebisch SJH, Bello A, Spitoni GF, et al. Emotional susceptibility trait modulates insula responses and functional connectivity in flavor processing. Front Behav Neurosci. 2015;9:297.

2. Hume D. Emotions and Mood. Available from: http://catalogue.pearson ed.co.uk/samplechapter/0132431564.pdf. Accessed March 12, 2016.

3. Millon T, Grossman S, Millon C, Meagher S, Ramnath R. Personality Disorders in Modern Life. 2nd ed. Hoboken, NJ: John Wiley \& Sons, Inc.; 2004. Available from: http://www.turkpsikiyatri.org/arsiv/ personality.disorders.millon.pdf. Accessed March 12, 2016.

4. Matthews G, Deary IJ, Whiteman MC. Personality Traits. 3rd ed. Cambridge, UK: Cambridge University Press; 2009. Available from: http:// assets.cambridge.org/97805218/87786/frontmatter/9780521887786_ frontmatter.pdf. Accessed March 12, 2016.

5. Hettema JM, Neale MC, Myers JM, Prescott CA, Kendler KS. A population-based twin study of the relationship between neuroticism and internalizing disorders. Am J Psychiatry. 2006;163(5):857-864.

6. Carducci BJ. The Psychology of Personality: Viewpoints, Research, and Applications. 2nd ed. Maiden, MA: Wiley-Blackwell; 2009.

7. Eysenck HJ. The Biological Basis of Personality. Piscataway: Transaction Publishers; 1970.
8. Poropat AE. The Eysenckian personality factors and their correlations with academic performance. Br J Educ Psychol. 2011;81(1):41-58.

9. Stults-Kolehmainen MA, Sinha R. The effects of stress on physical activity and exercise. Sports Med. 2014;44(1):81-121.

10. Kendall E, Murphy P, O'Neill V, Bursnall S. A report to the workers' compensation and rehabilitation commission. Western Australia: Center for Human Services, Griffith University; 2000. Available from: http://www.mentalhealthpromotion.net/resources/occupational-stressfractors-that-contribute-to-its-occurrence-and-effective-management. pdf. Accessed March 12, 2016.

11. Rabkin JG, Struening EL. Life events, stress, and illness. Science. 1976;194(4269):1013-1020.

12. Salleh MR. Life event, stress, and illness. Malays J Med Sci. 2008;15(4):9-18.

13. Shendarkar AT, Patil V. A study of stressors in medical college students (hostelities) in northern Maharashtra. J Indian Acad Forensic Med. 2013;35(3):227-229.

14. Salam A, Yousuf R, Bakar SM, Haque M. Stress among medical students in Malaysia: a systematic review of literatures. Int Med J. 2013;20(6):649-655.

15. Rahman NI, Ismail S, Binti TN, et al. Stress among preclinical medical students of University Sultan Zainal Abidin. JApp Pharm Sci. 2013;3(11):76-81.

16. Rahman NI, Ismail S, Ali RM, et al. Stress among the first batch of MBBS students of Faculty of Medicine and Health Sciences, Universiti Sultan Zainal Abidin, Malaysia: when final professional examination is knocking the door. Int Med J. 2015;22(4):1-6.

17. Eva EO, Islam MZ, Mosaddek AS, et al. Prevalence of stress among medical students: a comparative study between public and private medical schools in Bangladesh. BMC Res Notes. 2015;8(1):327.

18. Rahman NIA, Aziz AA, Zainal Zulkifli MA, et al. Perceptions of students in different phases of medical education of the educational environment: Universiti Sultan Zainal Abidin. Adv Med Educ Prac. 2015; $6: 211$.

19. Ismail S, Salam A, Alattraqchi AG, et al. Evaluation of doctors' performance as facilitators in basic medical science lecture classes in a new Malaysian medical school. Adv Med Educ Prac. 2015;6:231.

20. Vitaliano PP, Russo J, Carr JE. Heerwagen JH. Medical school pressures and their relationship to anxiety. J Nervous Mental Dis. 1984;172(12):730-736.

21. Morrison J. More on medical student stress. Med Educ. 2001;35(7): 617-618.

22. Lee J, Graham AV. Students' perception of medical school stress and their evaluation of a wellness elective. Med Educ. 2001;35(7):652-659.

23. Grant A, Rix A, Mattick K, Jones D, Winter P. Identifying good practice among medical schools in the support of students with mental health concerns: a report prepared for the General Medical Council. Cardiff: Cardiff University; 2013. Available from: http://www.gmc-uk.org/ Identifying_good_practice_among_medcal_schools_in_the_support_ of_students_with_mental_health_concerns.pdf_52884825.pdf. Accessed March 12, 2016.

24. Sharifirad G, Marjani A, Charkazi A, Qorbani M, Shahnazi H. Stress among Isfahan medical sciences students. J Res Med Sci. 2012;17(4):402-406.

25. Barikani A. Stress in medical students. JMedical Educ. 2009;11(1,2):41-44.

26. Abramovitch H, Schreier A, Koren N. American medical students in Israel: stress and coping - a follow-up study. Med Educ. 2000;34: 890-896.

27. Wolf TM, Randall HM, Faucett JM. A survey of health promotion programs in U.S. and Canadian medical schools. Am J Health Promot. 1988;3:33-36.

28. Bhagat V, Nayak RD. Neuroticism and academic performance of medical students. Int J Humanit Soc Sci Invent. 2014;3(1):51-55.

29. Bhagat V. Extroversion and academic performance of medical students. Int J Humanit Soc Sci Invent. 2013;2(3):55-58.

30. Barlow S. The five stages of emotional healing; 2016. Available from: http://susannabarlow.com/healing/the-five-stages-of-emotionalhealing/. Accessed March 12, 2016. 
31. Saravanan C, Kingston R, Gin M. Is test anxiety a problem among medical students: a cross sectional study on outcome of test anxiety among medical students? Int J Psychol Studies. 2014;6(3):24-31.

32. Bernhardt V, Rothkötter HJ, Kasten E. Psychological stress in first year medical students in response to the dissection of a human corpse. GMS Z Med Ausbild. 2012;29(1):Doc 12.

33. Yusoff MSB, Rahim AFA, Baba A, Ismail SB, Sidi H, Esa AB. (2013). Psychological distress of first year medical students who underwent two different admission processes during a stressful period. Sains Malays. 2013;42(3):423-428.

34. Lim VK. Medical education in Malaysia. Med Teach. 2008;30(2): 119-123.

35. Shahabudin SH. Medical education in Malaysia. Teach Learn Med. 1992;4(2):80-85.

36. Jayasuriya-Illesinghe V, Nazeer I, Athauda L, Perera J. Role models and teachers: medical students perception of teaching-learning methods in clinical settings, a qualitative study from Sri Lanka. BMC Med Educ. 2016;16(1):1.

37. Teddlie C, Yu F. Mixed methods sampling a typology with examples. $J$ Mix Methods Res. 2007;1(1):77-100.

38. Marshall MN. Sampling for qualitative research. Fam Prac. 1996; 13(6):522-526.

39. Raj B. Manual of the Medico-Psychological Questionnaire. Mysore: Swayamsiddha Prakashana; 1960.

40. Nunnally JC. Psychometric Theory. 2nd ed. New York: McGraw-Hill; 1978:21.

41. Barman MP, Hazarika J, Kalita A. reliability and validity of Assamese version of EORTC QLQ-C30 questionnaire for studying the quality of life of cancer patients of Assam. World Appl Sci J. 2012;17(5):672-678.

42. Kernis MH, Waschull SB. The interactive roles of stability and level of self-esteem: research and theory. Adv Exp Soc Psychol. 1995;27:93-141.

43. Rogers CR. A Theory of Therapy, Personality, and Interpersonal Relationships, as Developed in the Client-Centered Framework. Toronto, Canada: McGraw-Hill;1959. Available from: http://biblio tecaparalapersona-epimeleia.com/greenstone/collect/ecritos2/index/ assoc/HASH01a5/4583605e.dir/doc.pdf. Accessed March 30, 2016.

44. deCharms R. Personal Causation: The Internal-Affective Determinants of Behavior. New York, USA: Academic Press; 1968.

45. Deci EL, Ryan RM. Intrinsic Motivation and Self-Determination in Human Behavior. New York, USA: Plenum; 1985.

46. Valiente C, Swanson J, Eisenberg N. Linking students' emotions and academic achievement: when and why emotions matter. Child Dev Perspect. 2012;6(2):129-135.
47. McCabe L. Education Abroad. Mental Health and Study Abroad: Responding to the Concern. International Educator, 2005. Available from: https://www.nafsa.org/_/File/_/InternationalEducator/Edu cationAbroadNovDec05.pdf. Accessed February 13, 2016.

48. Oluwafunmilola OO. Depression Among International Students [thesis]. Finland: Central Ostrobothnia University of Applied Sciences; 2012. Available from: https://www.theseus.fi/bitstream/handle/10024/44723/ KEMI_OMODONA.pdf?sequence=1. Accessed February 13, 2016.

49. Berry JW. Acculturation: living successfully in two cultures. Int J Intercult Relat. 2005;29(6):697-712.

50. Wu HP, Garza E, Guzman N. International student's challenge and adjustment to college. Educ Res Int. 2015;2015:1-9.

51. Mustaffa CS, Ilias M. Relationship between students adjustment factors and cross cultural adjustment: a survey at the Northern University of Malaysia. Intercultural Communication Studies. 2013;1(22): 279-300.

52. Lee S, Bradley KD. Relation between general self-efficacy, assertiveness, spirituality, and acculturative stress among international students. In: Proceedings of the Mid-Western Educational Research Association Annual Meeting; 2005; Columbus, OH. Available from: http://www. uky.edu/ kdbrad2/InternationalStudents.pdf. Accessed February 13, 2016.

53. Thomson G, Rosenthal D, Russell J. Cultural stress among international students at an Australian university. In: Proceedings of Australian International Education Conference; 2006; Perth, Australia; 1-8. Available from: http://aiec.idp.com/uploads/pdf/Thomson $\% 20$ (Paper)\%20Fri\%20 1050\%20MR5.pdf. Accessed February 13, 2016.

54. Ibrahim NF, Yusof NSHC, Razak NFA, Norshahidi ND. A meta-analysis of the relationship between big five personality traits and students' academic achievement, Universiti Teknologi Mara, Malaysia. Proceeding of the Social Sciences Research ICSSR 2014 (e-ISBN 978-967-117687-0); 9-10 June 2014; Kota Kinabalu, Sabah, Malaysia. Organized by http://WorldConferences.net. Available from: http://worldconferences. net/proceedings/icssr2014/toc/papers_icssr2014/IC\%20063\%20 NUR\%20SAFWATI\%20BINTI\%20IBRAHIM\%20-\%20A\%20MetaAnalysis\%20Of\%20The\%20Relationship\%20Between.pdf. Accessed March 13, 2016.

55. Bob MH, Popescu CA, Pîrlog R, Buzoianu AD. Personality factors associated with academic stress in first year medical students. HVM Bioflux. 2014;6(1):40-44.

56. Lievens F, Coetsier P, De Fruyt F, De Maeseneer J. Medical students' personality characteristics and academic performance: a five-factor model perspective. Med Educ. 2002;36(11):1050-1056.
Advances in Medical Education and Practice

\section{Publish your work in this journal}

Advances in Medical Education and Practice is an international, peerreviewed, open access journal that aims to present and publish research on Medical Education covering medical, dental, nursing and allied health care professional education. The journal covers undergraduate education, postgraduate training and continuing medical education

\section{Dovepress}

including emerging trends and innovative models linking education, research, and health care services. The manuscript management system is completely online and includes a very quick and fair peer-review system. Visit http://www.dovepress.com/testimonials.php to read real quotes from published authors. 